\title{
Tissue Response and Immunoexpression of Interleukin 6 Promoted by Tricalcium Silicate-based Repair Materials after Subcutaneous Implantation in Rats
}

\author{
Aline S. Andrade, MSc, ${ }^{\star}$ Guilherme F. Silva, PbD, ${ }^{*}$ Josette Camilleri, PhD, ${ }^{\dagger}$ Estela S. Cerri, PbD, ${ }^{*}$ \\ Juliane M. Guerreiro-Tanomaru, PhD, ${ }^{*}$ Paulo S. Cerri, PbD, ${ }^{*}$ and Mário Tanomaru-Filbo, $P b D{ }^{\star}$
}

\begin{abstract}
Ahstract
Introduction: The aim of the present study was to evaluate the inflammatory response induced by experimental tricalcium silicate cement with $20 \%$ zirconium oxide (TSC) and MTA Plus (MTAP; Avalon Biomed Inc, Bradenton, $\mathrm{FL}$ ) in rat subcutaneous tissues. Methods: Polyethylene tubes were filled with TSC $(n=20)$ and MTAP $(n=20)$ and implanted in the dorsal subcutaneous tissues of 32 rats. Empty tubes were used as the control (control group [CG], $n=20$ ). After 7, 15, 30, and 60 days, the tubes with connective tissue were removed, and the inflammatory cells and immunolabeled cells for interleukin 6 (IL-6) were counted. Data were statistically analyzed using analysis of variance and the Tukey test $(P \leq .05)$. Results: An increased number of inflammatory and immunolabeled cells for IL- 6 were observed at 7 days. The number of inflammatory cells was higher for TSC and MTAP than the CG $(P<.001)$ at 7 days; after 30 and 60 days, no significant differences were observed among the TSC, MTAP, and CG $(P=.955)$. The number of immunolabeled cells for IL-6 was similar for TSC, MTAP, and CG at all evaluated periods. A gradual and significant decrease was observed in the number of inflammatory cells and IL6-immunopositive cells. At 60 days, the capsules adjacent to TSC and MTAP exhibited fibroblasts and bundles of collagen fibers. Conclusions: TSC and MTAP caused a similar subcutaneous reaction in rats, suggesting that they are biocompatible and present similar immune responses. (J Endod 2018;44:458-463)
\end{abstract}

\section{Key Words}

Biocompatibility, immunohistochemistry, interleukin 6, tricalcium Silicate, zirconium oxide
$M$ ineral trioxide aggregate (MTA) is a tricalcium silicate-based cement containing bismuth oxide $\left(\mathrm{Bi}_{2} \mathrm{O}_{3}\right)$ as a radiopacifier (1). Tricalcium silicate-based biomaterials have shown proper biological and physico-

Significance
The evaluation of the inflammatory response
induced by experimental tricalcium silicate cement
with $20 \%$ zirconium oxide and MTA Plus showed a
similar subcutaneous reaction in rats, suggesting
that they are biocompatible to be used as repara-
tive materials.
chemical properties (2-5). The replacement of $\mathrm{Bi}_{2} \mathrm{O}_{3}$ by other radiopacifiers has been proposed (6-8) because $\mathrm{Bi}_{2} \mathrm{O}_{3}$ interferes in the hydration of MTA (9), resulting in an increase in porosity and a reduction of material strength (10). Furthermore, bismuth oxide interferes in cellular proliferation (11), and calcium silicate-based materials containing $\mathrm{Bi}_{2} \mathrm{O}_{3}$ induce an inflammatory response in rat subcutaneous tissue (12).

Another disadvantage of some MTA materials is the presence of Portland cement as a major component, which may contain heavy metal contamination (13). MTA Plus (MTAP; Avalon Biomed Inc, Bradenton, FL) is composed of tricalcium silicate and dicalcium silicate added to $\mathrm{Bi}_{2} \mathrm{O}_{3}$ (14). As a material used in pulpotomies, MTAP produced calcium hydroxide and did not exhibit dental discoloration (15). Moreover, MTAP promoted a low immunoexpression of interleukin 1 beta and 1 alpha, inflammatory cytokines, and allowed mineralized tissue formation over the pulp tissue of rats (16). Gomes-Cornélio et al showed that MTAP presents biocompatibility and bioactivity in human osteoblastlike cells (17).

A manufactured tricalcium silicate cement $\left([\mathrm{CaO}]_{3} \cdot \mathrm{SiO}_{2}\right.$; Mineral Research Processing, Meyzieu, France) associated with zirconium oxide $\left(\mathrm{ZrO}_{2}\right)$ as a radiopacifier is used as reparative material (18). The association of $80 \%$ pure tricalcium silicate cement (TSC) and $20 \% \mathrm{ZrO}_{2}$ presents proper properties, such as solubility, radiopacity, compressive strength, setting time, and microhardness (3). Furthermore, this cement in contact with simulated tissue fluid showed bioactivity $(3,19)$. Despite these facts, until now, there is no other evidence of the biological in vivo response of this material reported in the literature.

The aim of the present study was to evaluate the tissue response promoted by TSC and MTAP in rat subcutaneous tissues. Morphologic and morphometric analyses and

From the Departments of * Restorative Dentistry and ${ }^{\ddagger}$ Morphology, Araraquara Dental School, UNESP-São Paulo State University, Araraquara, São Paulo, Brazil; ${ }^{\dagger}$ Institute of Clinical Sciences, College of Medical and Dental Sciences, University of Birmingham, Birmingham, UK.

Address requests for reprints to Dr Mário Tanomaru-Filho, Araraquara Dental School, UNESP- Univ Estadual Paulista, Rua Humaitá 1680, CEP 14801-903 Araraquara, SP, Brazil. E-mail address: tanomaru@uol.com.br 0099-2399/\$ - see front matter

Copyright $@ 2017$ American Association of Endodontists. https://doi.org/10.1016/j.joen.2017.12.006 
Basic Research-Biology

TABLE 1. Materials Evaluated and Used Proportions

\begin{tabular}{|c|c|c|c|}
\hline Group & Material & Composition & $\begin{array}{c}\text { Proportion } \\
\text { (powder/distilled water) }\end{array}$ \\
\hline $\begin{array}{l}\text { TSC } \\
\text { MTAP }\end{array}$ & $\begin{array}{l}\text { Cement tricalcium silicate* with } 20 \% \mathrm{ZrO}_{2}^{\dagger} \\
\text { White mineral trioxide aggregate }\end{array}$ & $\begin{array}{c}\text { Tricalcium silicate, zirconium oxide } \\
\text { Tricalcium silicate, dicalcium silicate, calcium } \\
\text { sulfate, silica, bismuth oxide }\end{array}$ & $\begin{array}{l}1 \mathrm{~g} / 340 \mu \mathrm{L} \\
1 \mathrm{~g} / 340 \mu \mathrm{L}\end{array}$ \\
\hline
\end{tabular}

MTAP, MTA Plus; TSC, tricalcium silicate cement.

*Mineral Research Processing, Meyzieu, France.

${ }^{\dagger}$ Sigma-Aldrich, St Louis, MO.

${ }^{\ddagger}$ MTA Plus; Avalon Biomed Inc, Bradenton, FL.

the immunohistochemical reaction for the detection of interleukin 6 (IL-6), a proinflammatory cytokine, were performed. The null hypothesis was that there would be no difference in tissue reactions caused by TSC and MTAP.

\section{Material and Methods}

The present research protocol was analyzed and approved by the Ethical Committee for Animal Research of Araraquara Dental School, UNESP, Araraquara, São Paulo, Brazil (Process CEUA no. 33/2014).
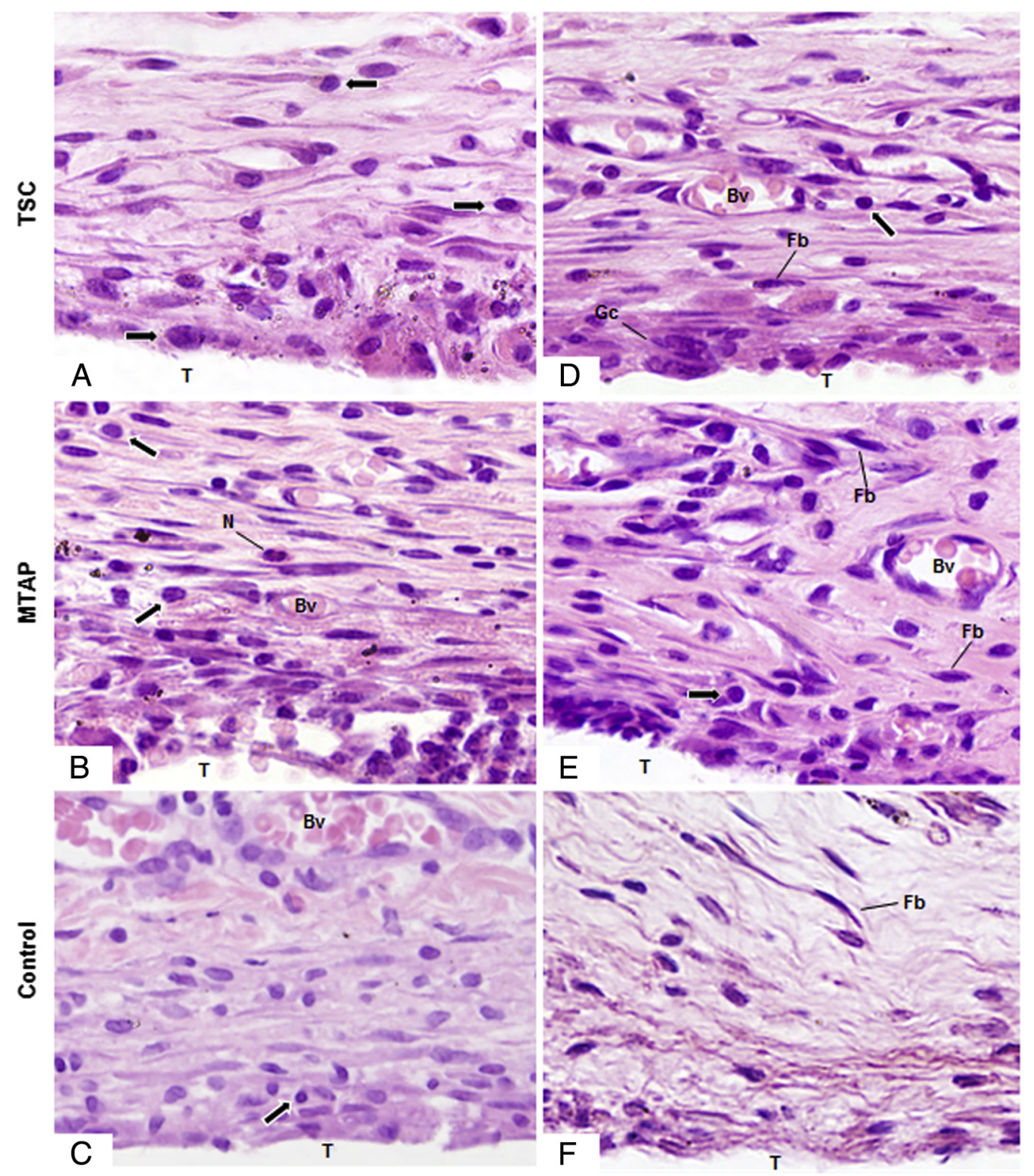

Figure 1. Light micrographs of sections showing portions of capsules adjacent to the opening of the tubes implanted (T) in the subcutaneous tissue after $(A-C) 7$ and $(D-F) 15$ days. $(A-C)$ Several ICs (arrows) are observed, mainly in the portion of the capsule adjacent to the opening of the tubes $(\mathrm{T})$. $\mathrm{N}$, neutrophil; Bv, blood vessels. $(D-F)$ ICs (arrows) among blood vessels (Bv) and fibroblasts (Fb). Gc, giant cells. Hematoxylin-eosin, $695 \times$. 

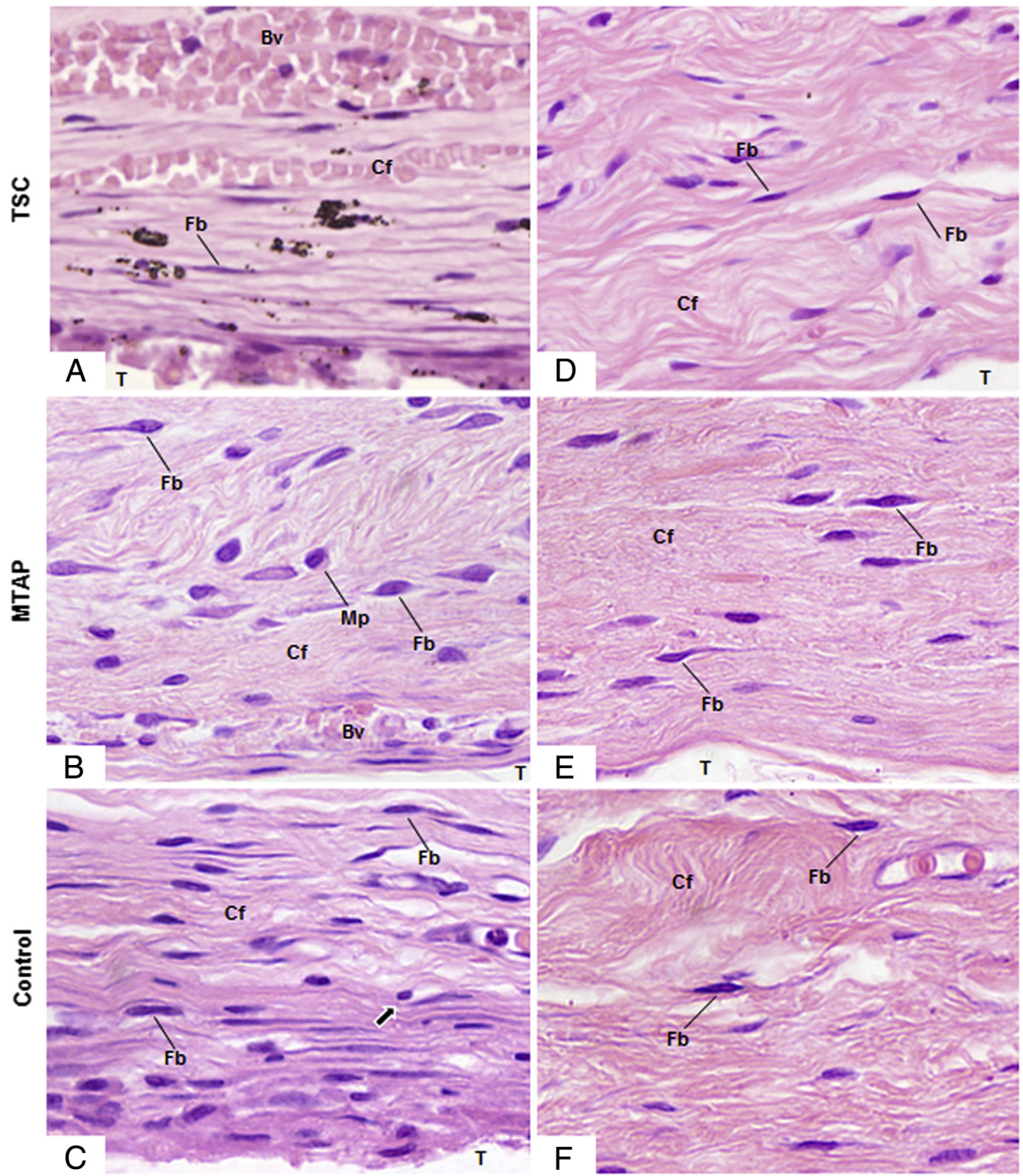

Figure 2. Light micrographs of sections showing portions of capsules adjacent to the opening of the tubes implanted (T) in the subcutaneous tissue after $(A-C) 30$ and $(D-F) 60$ days. Typical fibroblasts (Fb) are observed among bundles of collagen fibers (Cf) in the capsules. Few ICs (arrows) are present, mainly in the capsules of MTAP and the CG. Mp, macrophages; Bv, blood vessels. Hematoxylin-eosin, 695×.

In this study, 32 rats were used and distributed into 3 groups: TSC (TSC [Mineral Research Processing, Meyzieu, France] and 20\% $\mathrm{ZrO}_{2}$ [Sigma-Aldrich, St Louis, MO), MTAP, and a control group (CG, empty polyethylene tubes). The composition and proportion of the materials evaluated are described in Table 1.

After anesthesia with $80 \mathrm{mg} / \mathrm{kg}$ ketamine chloride $10 \%$ (Virbac do Brasil Indústria e Comércio Ltda, São Paulo, São Paulo, Brazil) and $8 \mathrm{mg} / \mathrm{kg}$ xylazine chloride 2\% (União Química Farmacêutica Nacional S/A, São Paulo, São Paulo, Brazil), administered by the intraperitoneal route, the dorsal skin was shaved and disinfected with $5 \%$ iodine solution. A $2-\mathrm{cm}$ incision was made with a no. 15 scalpel blade (Fibra Cirúrgica, Joinville, Santa Catarina, Brazil). Afterward, polyethylene tubes (Embramed Indústria e Comércio Ltda, São Paulo, São Paulo, Brazil), measuring $10 \mathrm{~mm}$ long $\times 1.5 \mathrm{~mm}$ in diameter, were filled with TSC or MTAP and immediately implanted into the subcutaneous tissue. The site of the incised skin was sutured with simple stitches using 4-0 silk thread (Ethicon Inc, São José dos Campos, São Paulo, Brazil). Two polythene tubes were used in each animal; 5 animals per group were used in each time point.

After $7,15,30$, and 60 days of implantation, the animals were euthanized with anesthetic overdose, and the implants with the surrounding tissues were removed. The specimens were immediately immersed in a formaldehyde $4 \%$ solution (prepared from paraformaldehyde) buffered with sodium phosphate $0.1 \mathrm{~mol} / \mathrm{L}(\mathrm{pH}=7.2)$ for 48 hours. After fixation, the specimens were dehydrated, treated with the xylene, and embedded in paraffin. Longitudinal sections $(6-\mu \mathrm{m}$ thick) were obtained and stained with hematoxylin-eosin for morphologic analysis and quantification of inflammatory cells (ICs) in the capsules. Other sections were adhered to slides previously treated with silane 4\% (Sigma-Aldrich) to perform the immunohistochemical reaction for IL-6 detection. 
TABLE 2. Numeric Density of Inflammatory Cells (ICs) and Interleukin 6 (IL-6)-immunolabeled Cells in the Capsules of the Tricalcium Silicate Cement (TSC), MTA Plus (MTAP), and Control Groups at 7, 15, 30, and 60 Days

\begin{tabular}{cccc}
\hline & TSC & MTAP & Control \\
\hline 7 days & & & \\
IC & $482.5(45.9)^{\mathrm{b}, 1}$ & $448.8(34.8)^{\mathrm{b}, 1}$ & $324.0(29.9)^{\mathrm{a}, 1}$ \\
IL-6 & $475.5(16.4)^{\mathrm{a}, 1}$ & $480.0(14.4)^{\mathrm{a}, 1}$ & $464.4(19.8)^{\mathrm{a}, 1}$ \\
15 days & & & \\
IC & $185.1(28.2)^{\mathrm{ab}, 2}$ & $214.8(43.6)^{\mathrm{b}, 2}$ & $154.0(8.1)^{\mathrm{a}, 2}$ \\
IL-6 & $185.1(28.2)^{\mathrm{ab}, 2}$ & $195.5(12.6)^{\mathrm{a}, 2}$ & $182.2(12.6)^{\mathrm{a}, 2}$ \\
30 days & & & \\
IC & $160.0(30.3)^{\mathrm{a}, 2}$ & $135.5(29.0)^{\mathrm{a}, 3}$ & $148.8(8.0)^{\mathrm{a}, 2}$ \\
IL-6 & $148.8(18.5)^{\mathrm{a}, 3}$ & $151.1(14.9)^{\mathrm{a}, 3}$ & $144.4(17.5)^{\mathrm{a}, 3}$ \\
60 days & & & \\
IC & $71.1(9.5)^{\mathrm{a}, 3}$ & $70.3(16.1)^{\mathrm{a}, 4}$ & $69.0(6.5)^{\mathrm{a}, 3}$ \\
IL-6 & $75.9(8.9)^{\mathrm{a}, 4}$ & $75.5(9.3)^{\mathrm{a}, 4}$ & $71.1(9.9)^{\mathrm{a}, 4}$ \\
\hline
\end{tabular}

Values are mean (standard deviation). The comparison among periods $(P<.05)$ is indicated by different superscript numbers in the various columns. The comparison among groups $(P<.05)$ is indicated by different superscript letters ( $a, b, c$, and $d$ ) in the various lines.

\section{Numeric Density of ICs}

The images were obtained with a digital camera (DP-71; Olympus, Tokyo, Japan) attached to a light microscope (BX-51, Olympus). The number of ICs was quantified using an image analysis system (Image Pro-Express 6.0, Olympus), as previously described (12). Quantitative analysis was performed in all samples or implants; in each implant, 3 hematoxylin-eosin-stained sections of the capsule were used at intervals of at least $100 \mu \mathrm{m}$. In each section, a standardized field of $0.09 \mathrm{~mm}^{2}$ of the capsule in close juxtaposition to the opening of the implanted tube was captured, totaling $0.27 \mathrm{~mm}^{2}$ per implant. In each field, the number of ICs (neutrophils, lymphocytes, plasma cells, and macrophages) was computed. In this way, in each implant, the number of $\mathrm{IC} / \mathrm{mm}^{2}$ was obtained. The numeric density of ICs was measured by 2 calibrated and blinded examiners.

\section{Immunohistochemical Reaction for the Detection of IL-6}

For IL-6 detection, the primary goat antibody anti-IL-6 (Santa Cruz Biotechnology Inc, Santa Cruz, CA) was used. Deparaffinized sections were immersed in $0.001 \mathrm{~mol} / \mathrm{L}$ sodium citrate buffer $(\mathrm{pH}=6.0)$ and submitted to microwave oven cycles for 20 minutes at $90^{\circ} \mathrm{C}-94^{\circ} \mathrm{C}$ for antigen retrieval. After cooling, the slides were washed in $0.05 \mathrm{~mol} / \mathrm{L}$ Tris-HCl buffer $(\mathrm{pH}=7.4)$ and subsequently immersed in $5 \%$ hydrogen peroxide for 20 minutes for blocking endogenous peroxidase. After washing, the sections were incubated with $2 \%$ bovine serum albumin (Sigma-Aldrich) for 20 minutes. Sections were incubated overnight in a humid chamber at $4^{\circ} \mathrm{C}$ with anti-IL-6 antibody diluted 1:100.

Subsequent to washing in Tris-HCl buffer, the sections were incubated for 40 minutes at room temperature with a multilink solution containing biotinylated rabbit/mouse/goat antibodies (LSAB; Dako Inc, Carpinteria, CA). After washing in Tris-HCl buffer, the sections were incubated with horseradish peroxidase complex (System-HRP, Dako Inc) for 40 minutes at room temperature. Subsequent to washing in buffer, peroxidase activity was revealed by chromogen 3.3-diaminobenzidine-HCl (DAB, Dako Inc) for 3 minutes. The sections were counterstained with Carazzi's hematoxylin. As a negative control, some sections were submitted to all the stages, except incubation with primary antibody; in this step, the sections were incubated in nonimmune serum.

\section{Numeric Density of Cells Positive for IL-6}

With the purpose of verifying whether there were differences among the groups, the number of IL-6-immunolabeled cells was estimated in the capsules of the 5 implants of each group/time point. As previously described, Image Pro-Express 6.0 Olympus software was used. The numeric density of IL-6-immunolabeled cells was obtained by 2 calibrated and blinded examiners. For each animal, the number of immunolabeled cells was quantified at $\times 695$ in a standardized field $\left(0.09 \mathrm{~mm}^{2}\right)$ of the capsule in close juxtaposition to the opening of the implanted tube. Thus, the number of IL-6-immunolabeled cells $/ \mathrm{mm}^{2}$ per animal was obtained $(8,12)$.

\section{Statistical Analysis}

The quantitative data were submitted to statistical analysis using the Sigma Stat 2.0 program (Jandel Scientific, Sausalito, CA). After normality was confirmed, 2-way analysis of variance and the Tukey test were used at a level of significance of $5 \%$.

\section{Results \\ Morphologic and Numeric Density Analysis of ICs}

At 7 days, the capsules in all the groups exhibited several ICs, mainly lymphocytes and macrophages among the blood vessels (Fig. $1 A-C$ ). At 15 days, the capsules contained fibroblasts and collagen fibers, particularly in the TSC group and the CG. However, ICs and blood vessels were still clearly observed in the capsules (Fig. $1 D-F$ ). Occasionally, some multinucleated giant cells were also observed, mainly in the internal portion of the capsules, adjacent to the materials (Fig. 1D). After 30 and 60 days, the connective tissue of the capsules contained several fibroblasts between the collagen fiber bundles; the scarce ICs were represented by plasma cells, macrophages, and mast cells (Fig. $2 A-F$ ).

Quantitative analysis revealed that in all the groups the number of ICs was significantly higher at 7 days. After this period, the statistical analysis of each group revealed a gradual and significant reduction in the number of ICs in the capsules of all groups $(P<.001)$ over time. At 7 days, no significant differences were verified between TSC and MTAP $(P=.592)$; however, these values were statistically higher in comparison with those of the CG $(P<.001)$. In turn, in the periods of 30 and 60 days, no significant differences were observed among TSC, MTAP, and the CG $(P=.955)$ (Table 2$)$.

\section{Immunohistochemical Detection of IL-6 and Numeric Density of Immunopositive Cells}

The sections of capsules submitted to the immunohistochemical reaction for IL-6 showed ICs (lymphocytes, plasma cells, macrophages, and mast cells) and some fibroblasts exhibiting positivity to immunoreaction. Morphologic analysis revealed immunolabeled cells in the capsules of all the groups; however, an accentuated immunopositivity was observed in the capsules at 7 days in comparison with the other periods (Fig. $3 A-L$ ). On the other hand, sections of capsules incubated without the primary antibody (negative control) exhibited no immunopositive cells (data not shown).

According to Table 2, the number of IL-6-immunolabeled cells was significantly higher at 7 days than at 15, 30, and 60 days. In all the groups, the number of immunolabeled cells was significantly reduced from 7 to 60 days. However, no statistically significant differences were detected among TSC, MTAP, and the CG in any of the periods.

\section{Discussion}

Histopathological analysis of the subcutaneous response after different experimental periods evaluates not only the tissue characteristics to irritant potential but also the duration of this effect on tissues $(5,20,21)$. The present study showed that TSC and MTAP induced 
TSC
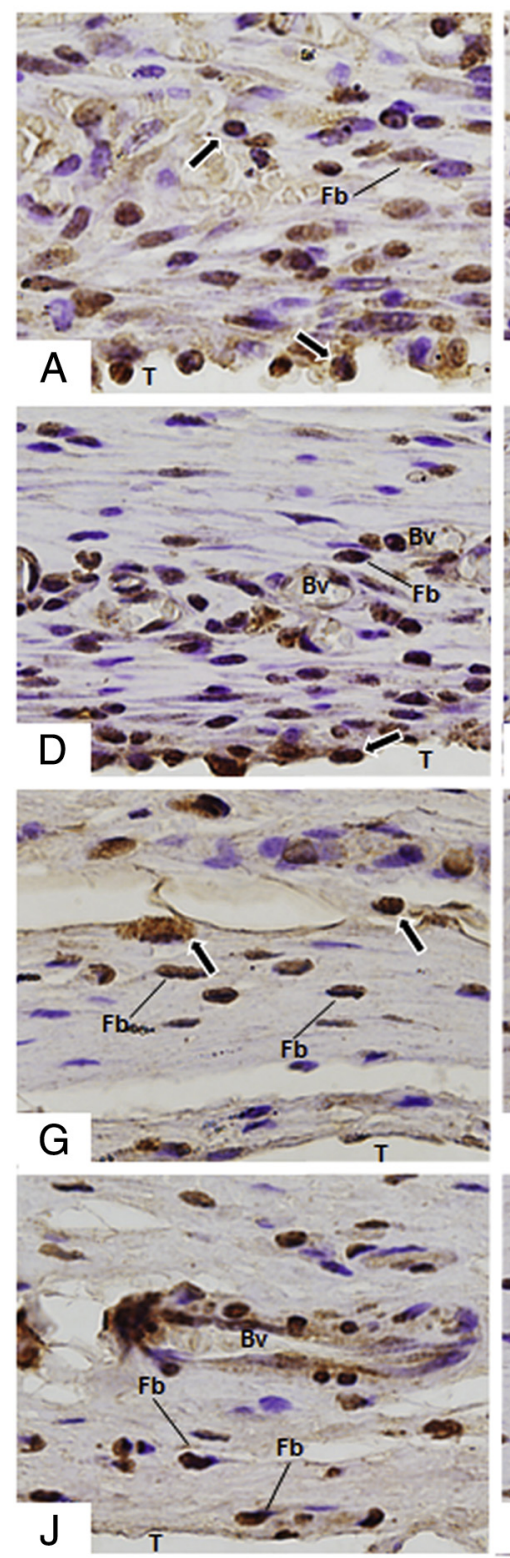

MTAP
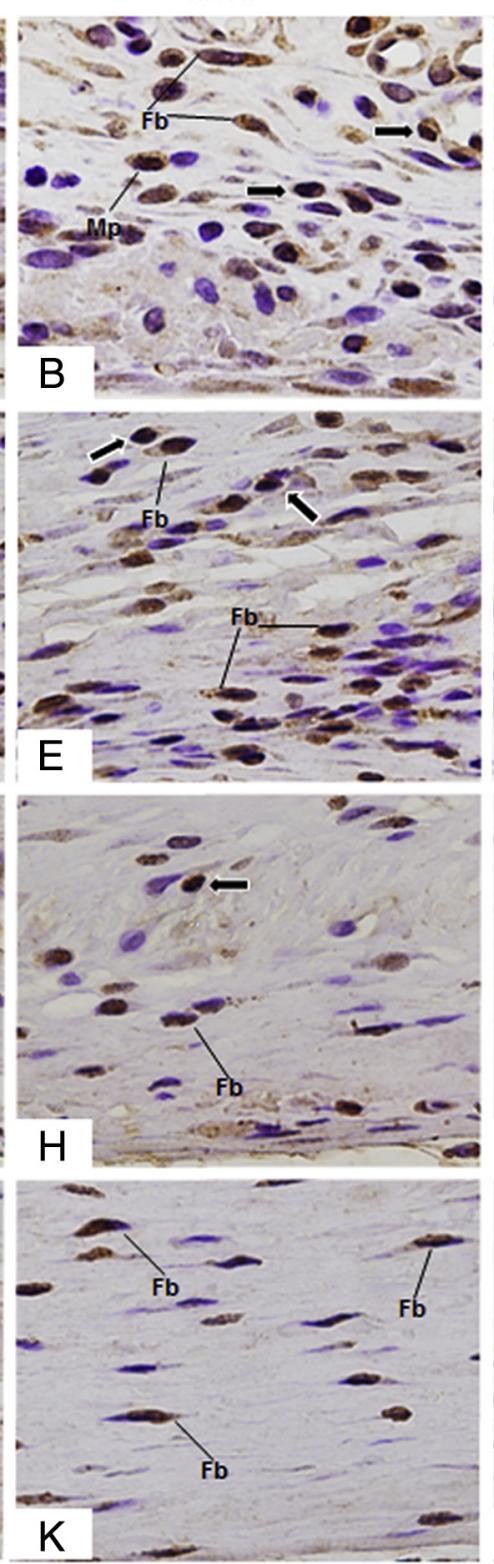

Control
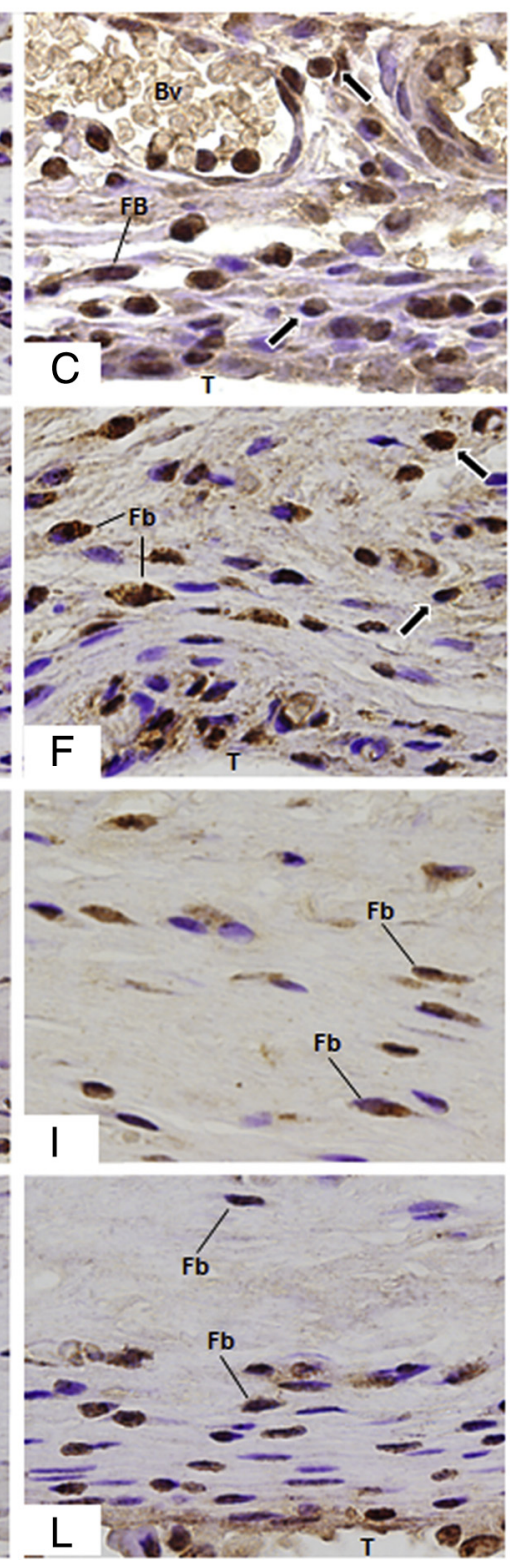

Figure 3. Light micrographs of sections showing portions of capsules adjacent to the opening of the tubes (T) implanted in the subcutaneous tissue after $(A-C) 7$, $(D-F) 15,(G-I) 30$, and $(J-L) 60$ days of implantation. Sections were submitted to immunohistochemistry reaction for IL-6 detection and counterstained with hematoxylin-eosin. Several immunolabeled cells (arrows, brown/yellow color), especially plasma cells, mast cells, and some fibroblasts ( $\mathrm{Fb}$ ), are observed in the capsules at 7 and 15 days. At 60 days, scarce cells exhibit immunolabeling for IL-6. Bv, blood vessels; Mp, macrophage. 500×.

an inflammatory reaction in the subcutaneous tissues. However, this reaction was gradually reduced, leading to the formation of dense connective tissue in the capsules. The reduction in the inflammatory reaction occurred concomitantly with the reduction in the immunoexpression of IL-6 in the capsules adjacent to the materials, indicating that the experimental TSC and MTAP are biocompatible materials. The inflammatory reaction initially caused by TSC and MTAP may be related to the hydroxyls $\left(\mathrm{OH}^{-}\right)$released after hydration of the materials, providing an environment with an alkaline $\mathrm{pH}(3,14,18)$. The alkaline $\mathrm{pH}$ stimulates recruitment of the leukocytes of the blood vessels $(8,12,22,23)$ and, therefore, may explain the higher values of ICs verified in the initial time point.

The tissue reaction observed is a consequence of the host response to substances released by the materials. Therefore, the host cells (inflammatory and resident) produce and release several cytokines and growth factors that play a specific role in the complex cascade of cellular events involved in the tissue response. Among the different cytokines, IL-6 is considered a powerful mediator of the inflammatory process (24).

An association has been observed between the reduction in immunoexpression of IL- 6 and a reduction in the inflammatory process in the capsules adjacent to the calcium silicate-based cements implanted in the rat subcutaneous tissues $(8,12)$, indicating that these materials do not have an irritating effect on connective tissue during a prolonged period.

The gradual and significant reduction in the number of immunolabeled cells for IL-6 suggests that the capsules adjacent to the materials implanted undergo an intense remodeling process from 7 to 
60 days. Moreover, our results point out that this cytokine may be involved in the response promoted by tricalcium silicate-based materials because a reduction in both immunolabeled cells for IL- 6 and in the number of ICs was observed. Considering that no significant differences in the IL-6 immunoexpression were observed for TSC and MTAP compared with the CG, it is possible to suggest a low irritant potential of the materials to the tissues. Despite this, the materials promoted a greater recruitment of ICs than the empty tube. Therefore, these materials may release some substances that stimulate the migration and differentiation of cells, such as macrophages and plasma cells, frequently observed in the capsules at 7 days. However, the inflammatory process was replaced by a capsule containing well-developed bundles of collagen fibers between fibroblasts at 30 and 60 days after implantation. This tissue response indicates that the materials are biocompatible.

It has been shown that $\mathrm{ZrO}_{2}$ added to calcium silicate cement promotes adequate physicochemical properties and a better biologic response than $\mathrm{Bi}_{2} \mathrm{O}_{3}$ (12). Nevertheless, in the present study, MTAP, which presents $\mathrm{Bi}_{2} \mathrm{O}_{3}$, promoted a subcutaneous tissue response similar to that of TSC. The hypothesis for this finding may be related to the fact that MTAP does not have Portland cement in its composition, but instead it has tricalcium silicate (approximately 50\%), dicalcium silicate, calcium sulfate, and silicon dioxide in addition to $\mathrm{Bi}_{2} \mathrm{O}_{3}$ (approximately 30\%). The substitution of Portland cement by tricalcium silicate and dicalcium silicate allows better control of heavy metals that are found in MTA (18), favoring the hydration reaction (3).

\section{Conclusion}

TSC and MTAP caused a similar subcutaneous implantation reaction in rats, indicating that both present a similar immune response. The significant reduction in the inflammatory reaction accompanied by the decrease in IL-6 immunoexpression in the capsules over time indicates that these tricalcium silicate-based materials may have potential as root repair material.

\section{Acknowledgments}

The authors thank Mr Pedro Sérgio Simões and Mr Luis Antonio Potenza for their kind help and technical assistance.

Supported by the São Paulo Research Foundation (FAPESP nos. 2015/03437-6 and 2014/13353-1).

The authors deny any conflicts of interest related to this study.

\section{References}

1. Camilleri J, Montesin FE, Brady K, et al. The constitution of mineral trioxide aggregate. Dent Mater 2005;21:297-303.
2. Camilleri J, Sorrentino F, Damidot D. Investigation of the hydration and bioactivity of radiopacified tricalcium silicate cement, Biodentine and MTA Angelus. Dent Mater 2013;29:580-93.

3. Grech L, Mallia B, Camilleri J. Investigation of the physical properties of tricalcium silicate cement-based root-end filling materials. Dent Mater 2013:29:20-8.

4. Camilleri J, Laurent P, About I. Hydration of Biodentine, Theracal LC, and a prototype tricalcium silicate-based dentin replacement material after pulp capping in entire tooth cultures. J Endod 2014;40:1846-54.

5. Taha NA, Safadi RA, Alwedaie MS. Biocompatibility evaluation of EndoSequence root repair paste in the connective tissue of rats. J Endod 2016;42:1523-7.

6. Bortoluzzi EA, Guerreiro-Tanomaru JM, Tanomaru-Filho M, Duarte MA. Radiographic effect of different radiopacifiers on a potential retrograde filling material. Oral Surg Oral Med Oral Pathol Oral Radiol Endod 2009;108:628-32.

7. Camilleri J, Cuttajar A, Mallia B. Hydration characteristics of zirconium oxide replaced Portland cement for use as a root-end filling material. Dent Mater 2011; 27:845-54.

8. Silva GF, Tanomaru-Filho M, Bernardi MI, et al. Niobium pentoxide as radiopacifying agent calcium silicate-based material: evalution of physicochemical and biological properties. Clin Oral Investig 2015;19:2012-25.

9. Camilleri J. Hydration mechanisms of mineral trioxide aggregate. Int Endod J 2007; 40:462-70.

10. Coomaraswamy KS, Lumley PJ, Hofmann MP. Effect of bismuth oxide radioopacifier content on the material properties of an endodontic Portland cement based (MTAlike) system. J Endod 2007:33:295-8.

11. Camilleri J, Montesin FE, Papaioannou S, et al. Biocompatibility of two commercial forms of mineral trioxide aggregate. Int Endod J 2004:37:699-704.

12. Silva GF, Bosso R, Ferino RV, et al. Microparticulated and nanoparticulated zirconium oxide added to calcium silicate cement: evaluation of physicochemical and biological properties. J Biomed Mater Res A 2014;102:4336-45.

13. Chang SW, Shon WJ, Lee W, et al. Analysis of heavy metal contents in gray and white MTA and 2 kinds of Portland cement: a preliminary study. Oral Surg Oral Med Oral Pathol Oral Radiol Endod 2010;109:642-6.

14. Formosa LM, Mallia B, Camilleri J. Mineral trioxide aggregate with anti-washout gel properties and microstructure. Dent Mater 2013;29:294-306.

15. Camilleri J. Staining potential of Neo MTA Plus, MTA Plus, and Biodentine used for pulpotomy procedures. J Endod 2015;41:1139-45.

16. Kramer PR, Woodmansey KF, White R, et al. Capping a pulpotomy with calcium aluminosilicate cement: comparison to mineral trioxide aggregates. J Endod 2014; $40: 1429-34$.

17. Gomes-Cornélio AL, Rodrigues EM, Salles LP, et al. Bioactivity of MTA Plus, Biodentine and an experimental calcium silicate-based cement on human osteoblastlike cells. Int Endod J 2017;50:39-47.

18. Formosa LM, Mallia B, Camilleri J. The effect of curing conditions on the physical properties of tricalcium silicate cement for use as a dental biomaterial. Int Endod J 2012; $45: 326-36$

19. Camilleri J, Formosa L, Damidot D. The setting characteristics of MTA Plus in different environmental conditions. Int Endod J 2013;46:831-40.

20. Zmener 0. Tissue response to a new methacrylate-based root canal sealer: preliminar observations in the subcutaneous connective tissue of rats. J Endod 2004;30: 348-51.

21. Shahi S, Rahimi S, Lotfi M, et al. A comparative study of the biocompatibility of three root-end filling materials in rat connective tissue. J Endod 2006;32:776-80.

22. Vosoughhosseini S, Lotfi M, Shahi S, et al. Influence of white versus gray mineral trioxide aggregate on inflammatory cells. J Endod 2008;34:715-7.

23. Shahi S, Rahimi S, Yavari HR, et al. Effect of mineral trioxide aggregates and Portland cements on inflammatory cells. J Endod 2010;36:899-903.

24. Azuma MM, Samuel R0, Gomes-Filho JE, et al. The role of IL-6 on apical periodontitis: a systematic review. Int Endod J 2014;47:615-21. 